\title{
Kartini's Views on Opium Problems in Java at the End of the 19th Century
}

\author{
Abdul Wahid \\ Department of History, Universitas Gadjah Mada, Indonesia \\ Email: kang_ahid@ugm.ac.id
}

\begin{abstract}
In the $1890 \mathrm{~s}$, the discourse on the negative effects of opium consumption among Native people turned into a political movement, which demanded that the Dutch colonial government reform its policies on opium. In the same period, Raden Ajeng Kartini, a priyayi (noble) woman from Jepara, developed her intellectual capabilities and thinking. Her letters, it was later discovered, contained critical ideas concerning the disadvantaged position of Javanese women. In addition to this, as an issue attracting greater public scrutiny, the opium problem also drew Kartini's attention, as evinced in at least two letters to Stella Zeehandelaar and Mrs. Abendanon-Madri. Curiously, Kartini's views on the opium problem have been given little scholarly attention in the rich literature on her life, with most scholarly work focusing on her "feminist" thoughts and ideas. For that reason, this article offers an analysis on this very specific aspect of Kartini's thoughts, delving further into its historical context and what it means in terms of her existing historical persona.
\end{abstract}

Keywords: colonial policy; Jepara; Raden Ajeng Kartini; opium problem

\section{INTRODUCTION}

For many Indonesians, Raden Adjeng Kartini is undoubtedly a unique and important historical figure and perhaps the most important and celebrated one in the country. In May 1964 the Indonesian government officially declared Kartini to be a national heroine; the first women to be given this honor. Her birthday, falling on 21 April, is commemorated as Indonesian Women's Emancipation Day which recognizes Kartini's contribution to the emancipation movement of Indonesian women. Up to the present day, Kartini has been projected as a symbol of Indonesian women's struggle to gain an equal position and justice in society and eliminate its patriarchic structure and culture. As a national heroine, Kartini's figure has been institutionalized through various kinds of memorialization, for example, through historical books, school textbooks, state ceremonies, socio-cultural festivities, arts and popular culture productions. Similarly, academic researchers have recently located Kartini as no longer just a national-level historical subject in Indonesia, but has become a "global icon" representing the voice of women from the colonized country, whose thoughts and ideas are remain relevant for today's women across the globe. Kartini's legacies are remembered and studied not only in Indonesia and the Netherlands, two countries that had a relationship of colonized and colonizer in colonial history, but also in other countries in the world. ${ }^{1}$

Kartini's thoughts continue to be a research subject for international researchers who use different approaches and analytical frameworks in their efforts to produce new perspectives on the importance of Kartini's thoughts. So far, there has been an impressive number of books and articles discussing Kartini; this number is likely to increase along with the growth of gender studies, feminist, and postcolonial research on women's history in the colonial world. For example, in the catalog of Leiden University Library, the list of books concerning Kartini 
in different world languages numbers about one hundred. This number increases if journal articles, book chapters, articles in popular media, popular books, fiction, and other literary works are included. This number shows the level of interest in Kartini's thoughts and their relevance to the global community and the strong interest among international researchers to examine and analyze further Kartini's legacy for present-day situation. ${ }^{2}$

The literature on Kartini can be classified into five groups: 1) books or publications of Kartini's letters to her Dutch friends; 2) biographies on Kartini; 3) thematic studies on Kartini's thoughts and ideas; 4) studies on the legacies of Kartini and their position in modern Indonesia (and beyond); and 5) literary works about or inspired by Kartini. The first group of literature is perhaps the most relevant one for this paper, which will be used as the main sources to delve into Kartini's thoughts about the opium problem. This group includes several editions of books containing Kartini's original letters and correspondence, which have been compiled, edited, and published in different languages, such as Dutch, French, English, and Indonesian. The first edition of Kartini's letter was published in Dutch in the Netherlands in 1911. The book was compiled and edited by J.H. Abendanon, a well-known supporter of the Ethical Policy - the Dutch colonial policy introduced in 1901 that aimed at lifting the living standard of native Indonesians, among other things, through education. ${ }^{3}$ Not long after this publication, another edition of Kartini's letter in the Indonesian language, edited by Armijn Pane, a prominent Indonesian writer, was published by Balai Pustaka Publishing house in 1938 (Kartini \& Pane (ed.), 1938) and was reprinted in 1949, 1951, 2002 and 2009. These Armijn Pane editions seemed to have been a primary reference on Kartini for Indonesian readers. In 1979, a new Indonesian version of Kartini's letters, edited by Sulastin Sutrisno was published (Kartini \& Sutrisno (ed.), 1979). By 1960, a French edition of Kartini's book, produced by two French academics L.C Damais and Jeanne Cuisinier, was published in Paris (Kartini \& Damais \& Cuisinier (eds.), 1964), while the first English edition of Kartini's letters was published in 1921 by Agnes L. Symmers, published in London (Symmers, 1921). Another English language version was published by a New York based publishing house in 1964, edited by Eleanor Roosevelt and Hildred Geertz (Kartini \& Roosevelt and Geertz, 1964).

Despite the fact that a sizeable number of books of Kartini's letters has been published, International researchers and academics from various institutions are continuously trying to find the remaining Kartini's letters that were not included in the previous publications. One of the most notable Kartini researchers, Joost Coté, a Dutchborn Australian historian, has been successful in collecting and compiling Kartini's letters from various institutions in the Netherlands and Australia and translating them into English. Throughout his career, Joost Coté has published four publications concerning Kartini and her letters, all of them in English. The books are Letters from Kartini: an Indonesian Feminist, 1900-1904 published in 1992, On Feminism and Nationalism: Kartini's Letters to Stella Zeehandelaar, 1899-1903 published in 1995, and Kartini: the Complete Writings 1898-1904 published in 2013. In addition to these books, Joost Coté published another book that contains letters of Raden Ajeng Roekmini, one of Kartini's sisters who was very close to Kartini and, according to Joost Coté, also had a strong connection to Kartini's letters and progressive thoughts (Coté 1992, 1995, 2008, 2013).

In each of these books, Joost Coté writes an introduction that provides not only an explanation about the research process that he undertook to produce the books, but also his analysis on Kartini's thoughts and their significance for modern Indonesian history and society. In the 2013 edition, which he claims as the most complete edition of Kartini's letters, Joost Coté writes a very long introduction. He discusses various aspects of Kartini's personality, thoughts, and struggle hitherto unpublished. For example, Kartini's ideas and visions on the local economy in Jepara and the way to improve it, according to Joost Coté, can be seen clearly from her letters and efforts she made to develop the exotic woodcarving industry by introducing it to the European market through participation in exhibitions (Coté 2013: 15-20). By doing so, Joost Coté shows that Kartini's thoughts were quite different and broader than a concern with the fate of Javanese women and her ideas to liberate them through education but extending to politics, culture, religion, and the native economy. In short, according to Joost Cote, Kartini is a female Javanese intellectual, social-political thinker, and activist for the local economy.

The second group of literature on Kartini is biographical books. Like the first group-Kartini's biographies, are written in academic as well as in popular styles but have been produced in large number, much more than the first group. The Leiden University Library holds the earliest biography of Kartini written in Dutch by C. Th. Van Deventer, an important figure behind the Ethical Policy, in 1912 (van Deventer, 1912). This biography is part of its collection of Indonesian and Asian history material, and is one of the largest in the world. Again, according to Joost Coté, van Deventer is the most important figures who introduced Kartini to Dutch society 
in the Metropolis, particularly as an "ideal type" of modern Javanese woman projected to be "educated" through the Ethical Policy. This biography was soon followed up by other biographical works written by Dutch academics and biographers. The first Kartini biography, written by an Indonesian author, Hurustriati Subandrio, appeared in 1950. This biography was followed by several other biographers, two of which were written by Siti Sumandari Suroto (Suroto, 1977) and Tashadi (Tashadi, 1975); both were reprinted several times in the following years due to strong demand from Indonesian readers.

Closely related to Kartini's biographical books are literary works — particularly novels, biographical works, poetry - and movies. One of the first novels about Kartini is the work of Marie C. van Zeggelen published in 1945 entitled Kartini: een baanbreekster voor haar volk: roman (van Zeggelen, 1945). Meanwhile, famous Indonesian writer Pramoedya Ananta Toer was one of the authors who produced a biographical work on Kartini, entitled Panggil Aku Kartini Saja (Toer, 2003). The book was published for the first time in 1962 but was then banned by the New Order Government along with his other works and was only republished in 2003 after the New Order collapsed. Aside from these works, there was another literary work in the form of poetry for children, which was written by Latif Syahril in 1983 (Latif 1983). As far as movies are concerned, up to the present there have been three movies about Kartini produced by Indonesian moviemakers. They are R.A. Kartini, produced in 1984 by Sjuman Djaja; Surat Cinta untuk Kartini produced in 2016 by Azhar Kinoi Lubis; and Kartini produced in 2017 by Hanung Bramantyo (Fathurrozak, 2020).

The next group about Kartini is academic works produced by academics and researchers that investigate thematically Kartini's letters using different approaches and theoretical frameworks. This type of work has also been sizeable in number, which shows the broad range of Kartini's thought and its ongoing relevance. One of the most recent and highly innovative writings that exemplify this group is Paul Bijl's article published in 2017, which reveals human rights aspects of Kartini's thoughts (Bijl, 2017: 51-71).

Some Indonesian academics have also produced interesting works on different aspects of Kartini's thought and life. Th. Sumartana, for example analyzes religious and theological aspects in Kartini's letters and thought (1993, republished 2013). This is perhaps the best work, which reveals Kartini's struggles and her intellectual search concerning religious issues. Suryatini N. Gani produces another interesting and innovative work, which discusses gastronomical aspects in Kartini and her sisters' lives (Gani, 2005). This book reveals Kartini's daily life as a "princess" in a Javanese court and daughter of a Bupati, the head of a regency, aspiring to a befitting Javanese culture and lifestyle, including in cuisine and foods. The last two books by Efatino Febriana (Febriana, 2010) and Amirul Ulum seek to unveil freemasonry and Islam's influence in Kartini's letters and thought (Ulum, 2019). Febriana argues, based on very limited evidence, Kartini's progressive thought was influenced by the Jewish-inspired free-thinkers' movement through her contacts and friendship with several members of freemasonry organization. Similarly, based on very slight evidence, Ulum underlines the importance of Islam as part of Kartini's intellectual journey, especially after she met Kyai Saleh Darat, a famous cleric in the region of Java's North Coast, who impressed Kartini with his answers on several issues related with the position of women in Islam. Ulum goes further to argue that this meeting was the moment for Kartini to become a santri, Islamic student of Kyai Saleh Darat. Regardless of their methodological flaws, these two books exemplify Indonesian scholars' ongoing academic endeavors to understand Kartini's thought with new themes and approaches.

The last literature group about Kartini is those studying Kartini's legacies and impacts in present-day Indonesia and other countries in the world. Reawyn Connell's article published in 2010 is one of the examples of this group, using a gender perspective in global education sees Kartini's thoughts as an inspirational (Connel, 2010: 603-615); while Petra Mahy's works published in 2012 critically reviews the practice of Kartini's commemoration in Indonesia and the role of media in this "national ritual" (Mahy, 2018: 33-48). The work of some Indonesian scholars is also found in this group. Suryanto Sastroatmojo writes about Kartini's image as being a part of an ideal type of Indonesian culture (Sastroatmojo, 1970); Solichin Salam extensively describes the position of Kartini in the national history of Indonesia (Salam, 1983); Suryanto Sastroatmodjo takes Kartini as a model for the women's emancipation movement in Indonesia (Sastroatmodjo, 1977); and Soekesi Soemoatmodjo presents an historical analysis on the role of the Kartini school, a special indigenous school for girls established to honor Kartini, in providing basic education (Soemoatmodjo, 1981).

From all literature mentioned above, Th. Sumartana's book is the only work that mentions Kartini's views on the opium problem. Yet, Sumartana discusses it very briefly and in passing while he delves into Kartini inner struggle concerning religion and God, which is the focus of his study. According to Sumartana, Kartini's 
view on the opium problem is part of her concern on "the declining welfare of indigenous people," the heavy tax burden, pandemic, and poor health conditions (Sumartana, 2013: 28-29). James Rush's classic study on the opium business in nineteenth-century Java also briefly references Kartini's critical view on the opium issue. Rush argues that Kartini's critical voice on opium provided important momentum for the rise of new awareness among priyayi, Javanese nobility, on the negative effects of opium consumption towards Javanese society. Such a political stand was replicated by Budi Utomo, the priyayi organization, one of the pioneering modern nationalist movements in Java, around one decade later (Rush, 2007: 253).

Based on the discussion above, this article seeks to investigate further Kartini's views on the opium problem in Java, the origins and historical context of Kartini's views, and the possible connection of Kartini's views with the anti-opium movement in several big cities in Java that emerged during Kartini's upbringing. The main question to be answered is why was Kartini concerned with the opium problem in Java, particularly in Jepara and Rembang, at that time? This will be followed up with several related questions: how serious was the opium problem given that she felt it necessary to write about it in some of her letters to her Dutch friends? What was Kartini's view on this opium problem which she had seen in her neighborhood in 1890s Jepara? Where did she get the information about the opium problem from? And to what extent does empirical evidence from the colonial sources support Kartini's view on the opium problem?

By asking these questions, this article aims to provide a more comprehensive understanding of Kartini's views concerning the opium problem, and as to how Kartini came up with her anti-opium ideas, or - in other words - about the historical context of her ideas. As such, this article is intended to make a new contribution to both Kartini historiography and the historiography of opium. The article starts its discussion with a short biography of Kartini, emphasizing how she gained her social sensitivity and sharp-mindedness concerning social problems, especially opium addiction, faced by indigenous people living in her environment in Jepara. The next section discusses in detail, with in-depth analysis, Kartini's views on the opium problems. The validity of Kartini's view will be examined in the last section by comparing it with the historical data about opium distribution and consumption in Jepara and Rembang, where Kartini spent her early life as the daughter of a Bupati and her last days as a wife of a Bupati.

\section{KARTINI: A RESTLESS JAVANESE PRINCESS}

Kartini was born on 21 April 1879, in a Javanese priyayi (noble) family, with her father being a wedana, head of a district in Mayong village. Her father was promoted later to be a bupati, residency head, of Jepara, gaining the royal title of Raden Adipati Sosroningrat. Kartini was the fifth daughter of Ngasirah, the first wife of her father, who was married at the age of 14 when his father was still holding office as the wedana. Ngasirah came from an ordinary family, and was the daughter of Kiai Modirono and Nyai Siti Aminah. Her father was a local Muslim preacher in Telukawur Village, Jepara. Ngasirah had to accept the reality that her husband would marry Raden Ajeng Moerjam, a priyayi woman from Madura, when he was appointed as bupati (regent). It was a common practice among Javanese priyayi to take a wife from another priyayi family to maintain and strengthen their socio-cultural position under the framework of the colonial political structure. Following the local tradition, Raden Adipati Sosroningrat would choose Raden Ajeng Moerjam as his primary wife and leave Ngasirah as selir, a secondary wife who had no privileges. In this position, Ngasirah had to address her own sons and daughters with their noble titles as raden mas or raden ajeng, because they had inherited their father's royal blood as a bupati. Even though it was a tradition and normal praxis at that time, it was an unacceptable practice for Kartini. According to Sumartana, Kartini's rejection of the tradition was the main source of her restlessness and discontentment that contributed to her rebellious attitude since childhood. ${ }^{4}$

It was quite fortunate for Kartini that her father Raden Adipati Sosrodiningrat was an open-minded and visionary bupati hence tolerating her "wild" childhood attitude. ${ }^{5}$ Compared to other Javanese bupati, Raden Adipati Sosrodiningrat was indeed quite exceptional due to his appreciation of Western education. It can be seen from his decision to send his sons and daughters to Dutch schools. He even sent Raden Mas Sosrokartono, Kartini's brother, to continue his education in the Netherlands. Yet, the supportive attitude of Bupati Sosrodiningrat apparently applied only to his sons' education, and he showed an inconsistent attitude in his decision concerning his daughters' education. Bupati Sosrodiningrat did not allow Kartini to get a higher-level education, and he thought that it was sufficient for Kartini to just complete her education at at a Dutch primary school, Europeeshce Lagere School (ELS). Even worse than this, Bupati Sosrodiningrat decided later to keep Kartini in pingitan or "customary custody" when she turned twelve years 
old. Under such conservative practices, Kartini was forbidden to leave the house until the time came for her to receive a proposal from a priyayi to marry her. As might be expected, this restriction deeply disappointed Kartini, but she could do nothing except accept and respect her father's decision. ${ }^{6}$

In 1892, Kartini- together with two of her sisters Roekmini and Kardinah — started their long-term pingitan, which locked them up physically for many years to come. In fact, during this period, Kartini was not completely disconnected from the outside world, as she still had a chance to have regular visits to Mevrouw Ovink, an incidental "picnic" to Semarang, and a wide access to journals and newspaper, and to "international information" via her correspondence with Stella Zeehandelaar and her brother Sosrokartono. So, for Kartini the pinigitan period became a period of contemplation, during which time she did an inner search and experienced a struggle that she expressed in her letters. With her ability to read and write in Dutch that she learned during her schooling, Kartini was immersing herself in books and reading, most of which were sent by her brother Sostrokartono, who was then already in the Netherlands. The most important catalyst for Kartini, however, to "see" the outside world was her acquaintance with Marie OvinkSoer, the wife of the Assistant Residence of Jepara, Mr. Ovink, who commenced his term of office in this area just before Kartini started her pingitan. Marie OvinkSoer was a productive writer and contributor to a Dutch women's magazine, De Hollande Lelie, led by Johanna van Woude. From her friendship with Marie, Kartini learned many things, including feminism, paintings, Dutch language, and writing skills. Furthermore, thanks to Marie's persuasion, Bupati Sosrodiningrat was finally willing to subscribed to De Hollandse Leie for Kartini. After becoming an enthusiast reader of that magazine, Kartini took the liberty to send Johanna van Woude a letter asking for her help to find her a penfriend from the Netherlands. Johanna happily met Kartini's request and finally found Estelle Zeehandelaar, a feminist, who was willing to be Kartini's penfriend (Chudori \& Redaksi KPG (ed.), 2013: 15-16).

From that time on, Kartini had a regular Dutch correspondent to discuss and share information through letters - about many aspects of the Western modern world and the "traditional" world of the East. As time passed, Kartini made more Dutch friends leading to an increased correspondence with those in her friendship circles in the Netherlands. Based on the addresses of letters that Kartini received, there were some ten names and addresses of Kartini's penfriends, the majority of whom were women.
In general, these women were well educated and of high social standing in the Netherlands at that time. ${ }^{7}$ From her correspondence with these Dutch ladies, Kartini gained a lot of information and knowledge about Western ideas and discourses that were popular in the Netherlands, including the Ethical Policy discourse. In response, Kartini also learned to formulate her observations concerning various problems found in Javanese society which she articulated in her letters to her Dutch penfriends. According to Sumartana, Kartini's letter contain at least three main issues, which become her main concerns, namely the emancipation of Javanese women, education in Javanese society, and the poor condition of the Javanese population due to various problems including opium consumption (Sumartana, 2013: 14-15).

\section{KARTINI'S VIEWS ON THE OPIUM PROBLEM}

Kartini's views and ideas about the opium problem form a small part of her socio-political ideas that are contained in the letters she sent to her pen friends. There are only two out of hundreds of letters in which Kartini explicitly expresses her views on the opium problem in Java, and elsewhere in the colony. The first is in her introductory letter to Estella (Stella) Zeehandelar written in Jepara on 25 May 1899, and the second one is in her letter to Mevrouw Rosa Abendanon-Madri, the wife of Jacques Abendanon, written in Rembang on 10 Agustus 1904. From the date and place of origin of the letters, it can be discerned that the two letters had a very different timeframe and historical context. The first letter was written when Kartini was still in Jepara while she in pingitan In this letter her excitement and enthusiasm is evident in having a pen friend from the Netherlands. Meanwhile, the second letter was written when she was in Rembang after her marriage to Raden Adipati Djojoadiningrat, the Bupati of Rembang, who already had three wives (selir). It was one of the last two letters of Kartini, sent one month prior to her death after giving birth to her first baby. The following paragraphs discuss the two letters in detail.

In her long letter to Stella Zeehandelaar, Kartini explains her admiration for modern European civilization. Therefore, according to her, many indigenous people wanted to follow and replicate many of the advances found in European civilization. However, Kartini further explains, many indigenous people uncritically adopted bad practices found in the West that cause social problems such as drinking alcohol. In that context, Kartini reveals her concern and anxiety about the bad Western habits, as follow: 
"In Native society, thank God, we do not yet have to fight against the demon drink - but I fear that when once-forgive me-Western civilization becomes established here we will also have to contend with that evil. Civilization is a blessing, but it also has its darker side. The urge to imitate is inherent in human beings, I believe. The masses imitate the habits of their betters, who in turn follow those of the higher classes and ultimately these imitate those at the very top - the Europeans. It is not a real celebration here if there is no accompanying drink. These days one regularly observes when Natives are celebrating - at least where they are not strictly religious, and most are only Muslim because their father, grandfather and other ancestors were Muslim - in reality, they are nothing more than heathens - that one or more of those square bottles are frequently being attended to. ${ }^{8}$

From the quotation above, it is clear what Kartini means as being a bad aspect of European culture adopted by Indigenous people namely, drinking liquor, commonly served during celebrations. Kartini critically notes that such bad habits were also adopted by Muslims, who supposedly knew that their religion prohibited this kind of deed. For Kartini, it really showed that they professed to be Islam, not from their heart but had only inherited it from their parents or great parents, from tradition. As a result, their behavior did not reflect someone with Islamic faith or a believer ( $m u^{\prime} \mathrm{min}$ ), but were just like other nonbelievers. That was a sharp and harsh criticism for this element in the Muslim community from a priyayi woman. Yet, Kartini expressed an even harsher view on opium, as can be seen from the following quotation:

"There is one evil here much worse than alcohol! It is opium. Oh! The misery which that disgusting substance has brought to my country, to my people, is beyond words. Opium is the plague of Java. Yes, opium is much worse than the plague. The plague does not last forever; sooner or later it subsides but the evil caused by opium is increasing rapidly, is spreading more and more and will not ever disappear simply because it is protected by the Government!" (Coté, 2013: 71; Kartini \& Ari P, 2018: 5).

In this quotation, Kartini uses very strong words to condemn candu or opium as "the evil worse than alcohol." Kartini also equates opium with "the plague or the plague of Java." In the context of 19 century Java, the plague wasre current and had high mortality rates before the invention of the vaccine (Baha'Uddin, 2000: 103-123). By using the plague as an analogy, Kartini wanted to emphasize the danger of opium consumption for health, which according to her, its effect was much more dangerous than the plague. Kartini stressed the plague's danger was not permanent and lasted only for a certain period. On the contrary, the threat and danger of opium were timeless; the longer it exists, the bigger risks it creates, and there is nothing that can stop it, not even the government.

Interestingly, in the subsequent section of her letter, Kartini boldly "attacked" the Netherlands Indies Government, for taking large profit from the opium business. Kartini writes that:

"The greater the use of opium in Java, the fuller the Treasury will be. The opium contract is one of the most profitable sources of income for the Netherlands Indies Government. What does it care if the people prosper or not as a result? - the Government benefits, that is the main point. The curse of the people fills the purse of the Netherlands Indies Government with thousands, with millions worth of gold" (Coté, 2013: 71; Kartini \& Ari P, 2018: 5).

So, in Kartini's view, the Dutch colonial government was not making any serious effort to reduce opium consumption. The government was permitting and creating the conditions for the population to use more opium, which in the long run contributed to the increase of opium consumption. This mainly has to do with the enormous profit that the colonial government gained from the opium business, which according to Kartini its value was worth "thousand or million guilders of gold." Meanwhile, the colonial government looked the other way and ignored the negative effects of opium consumption by the population. Considering the letter's historical context, it is very likely that Kartini's view refers to the period before 1895 when the colonial government applied an opium revenue farming system or opiumpacht, which was leased mostly to the Chinese businessmen. This system was very effective, allowing the colonial government to extract profit from opium, even though in the long run it also gave enormous financial benefit for the opium lease holder (opiumpachter). This system was gradually abandoned and reformed from the mid-1890s. Yet, at the time Kartini was writing her letter, the reformation process was still in progress. Hence many of the problems arising from the system remained unsolved. ${ }^{9}$

What was actually the evil or negative effects 
of opium consumption, according to Kartini? Kartini responds to this question as follows:

"Many say that the use of opium can do no harm but those who maintain this have never seen the Indies or are blind to what is before them.

No harm?! What, then, are the numerous murders, arsons, robberies which are the immediate consequence of the use of opium? No, taking opium is not evil as long as you can do it, as long as you have the money to buy the poison; but, when you cannot, when you have no money to buy it and you are an addict, then you are dangerous, then you are lost. The hunger in your belly can turn you into a thief, but the hunger for opium turns you into a murderer. There is a saying 'At first you consume opium, but in the end, opium will devour you'. And this is very, very true!"”

Oh God! Oh God! It is terrible to see so much evil around you and to be powerless to do anything against it. A year ago, I read in one of the daily papers that the government had prohibited the sale of morphine in the opium outlets because the use of morphine would lessen the use of opium. ${ }^{10}$

From this paragraph, it can be discerned that the evil or negative effects of opium use were various social problems that arise from opium consumption, particularly those who had become addicted. So, it was not only the impact on health that became Kartini's concern but also on the indigenous population's social-economic life in general,witnessed by anyone who had ever come to visit the Netherlands Indies. The most obvious opium-related social problems, according to Kartini, were theft, burning of houses or properties, and murder. All these crimes occurred when or committed by opium users who ran out of money or property, so they lost their financial capacity to meet their opium-hunger which led them to commit crimes. Kartini believed in the saying that "at first people enjoy consuming opium, at the end opium devours them". For Kartini, the saddest thing about this reality was that no single individual or group in indigenous society who had the courage to speak out, voicing the problem and demanding the colonial government take preventive measures.

In the literature, the problems Kartini mentions have been labeled "opium-problems" (opiumproblemen), which include addiction, declining public health, impoverishment through debt, criminality, and poverty. ${ }^{11}$ The problems emerged and began to attract the colonial government's attention and colonial policy observers from the early $1880 \mathrm{~s}$. The colonial government formed and assigned a team to organize an investigation into opium distribution, consumption, and its impacts on Javanese and Madurese society's socio-economic life in the mid-1880s. At the same time, a group of Dutch liberalhumanitarian activists started to campaign against the effects of opium consumption and demanded the colonial government abolish the existing opium business in the colony. ${ }^{12}$ In fact, at the time Kartini wrote her letter, there was indeed no single person or group in indigenous society trying to do something to respond to the rising opium problem in Java. Anti-opium Bond was so far the only pioneering group that spoke up about the opium problem.

Kartini's critical views on opium can also be seen clearly in another letter that she wrote from Rembang on 10 August 1904. Unlike the previous letter that seems a shade "softer," in this letter, Kartini "attacked" the colonial government for being ignorant and irresponsible in relation to the increase of opium-related social problems. The following quotation conveys the essence of Kartini's criticism against the colonial government:

"Several years ago when the opium monopoly was going to be introduced and Government officials came here to discuss it, my husband asked what actually the government's objective was with this regulation. He was told it was to discourage the use of opium amongst the native population.

'Is that really the intention? Does the government really want to dissuade the native people from using opium?' my husband asked again. Yes, it was seriously intended. Now, if that was so my husband knew of a simple method that at the same time would not cost the Government anything. And he offered to take upon himself the responsibility to end the use of opium in his regency in a few years." (Coté, 2013: 680-681).

In the quotation above, Kartini directed a harsh criticism against the colonial government, which was about to introduce a new opium policy called opiumregie stelsel, the opium monopoly regime. In the literature, this new opium policy was theoretically intended as not only a replacement but also an improvement of the previous policy known as opiumpacht or opium revenue farming system whose implementation relied heavily on the role of Chinese opium farmers. Under this new system, the colonial government controlled the entire supply chain of the opium business from importation, manufacturing, 
distribution to consumption. By introducing this system, the colonial government sought to restrict opium consumption to certain users, whose numbers would diminish naturally as time passed (Wahid, 2013: 185214).

Kartini and her husband, the Bupati of Rembang, were skeptical about the colonial government's sincerity in reducing opium consumption, particularly among indigenous people. Hence, the Regent of Rempang offered himself to be the one responsible for eliminating the opium business in his area over years to come. By doing that, the regent seemed to be trying to bluff the colonial government to ascertain their seriousness in implementing a policy to attentuate opium use. His bluff proved successful as the colonial government refused immediately his offer, which in the eyes of Kartini such a response was true evidence of the government's hypocrisy and lies. She wrote further:

"But what was the reply from a member of the council of the Indies? 'Regent you are in too much hurry, don't forget the government itself is still in need of money.'

So you see, it is not the Native population but the Government that cannot do without the opium. It is bitter but true; the curse of the Javanese is the lifeblood of the government. Why this fencing with words? Why is it being suggested that it is its serious desire to free the Javanese from the curse of opium?" (Coté, 2013: 681).

By examining the colonial officer's answer to her husband's question, Kartini confirms her doubts that the colonial government was insincere in addressing the opium problem, and that the opium monopoly policy was no more than political lip service. Kartini believed that financial profit was the government's focus, and it could not afford to lose the big revenue from opium sales. At the same time, the government - as happened before - did not pay attention to the fate of the indigenous people, who had to bear the high price of opium consumption. According to Kartini, it was a bitter truth that had to be accepted, that the colonial government would never be committed to liberating the Javanese people from the grip of opium addiction.

The passage from Kartini's letter above really shows how Kartini maintained her critical stance and attitude towards the colonial government policy on opium, even though she was married to a high-profile indigenous bureaucrat, the regent of Rembang. Despite her decision to accept the regent's marriage proposal and be in a polygamous relationship, and her hatred for polygamy, it did not alter her affection and commitment to help ordinary people living around her. ${ }^{13}$ The critical attitude that Kartini showed in her letter forced Jacques Abendanon, in his editing of a compilation of her letters, to omit the sections on opium, but leave other sections of the letter containing Kartini's critical voice over the poverty of Javanese people in general and her view on the government comprehensive investigation on the cause of Javanese poverty (mindere welvaart onderzoek), which according to her the survey was far too difficult to be answered objectively by indigenous people. Hence, the final result is deficient and not reliable. Abendanon's decision to censor Kartini's criticism against the opium policy is because the opium problem had become a sensitive political issue in Java at that time.

In this second letter, it is obvious that Kartini gained first-hand information about the colonial government's policy on opium directly from her husband, the regent of Rembang. Based on this information she then formulated her critical opinion on the colonial government's position on the opium problem. Yet it is not clear how Kartini could express an equally critical observation of the opium problem in Java in her first letter while she was under her father's enforcement of the pingitan tradition. Where did her information come from, and how did Kartini get the information? Was it the people around her-her sisters in particular, who supplied information and support Kartini's contemplation and struggle to grapple with issues, especially on the opium problem? These question will be discussed in the following section.

\section{SOURCES OF INFORMATION AND HISTORICAL CONTEXT OF KARTINI'S IDEAS}

Theoretically, there are three possible ways as to how Kartini collected or gained information about society's social condition in her community concerning the social effects of opium consumption. Firstly, Kartini was updating herself about local, "national" as well as the situation overseas through newspapers, magazines, books, and other reading material provided by her father when she was confined to the house. Secondly, concerning her knowledge of opium problems, Kartini directly observed the condition of indigenous people and problems they faced from their habit of opium consumption before and after her pingitan. Third, Kartini received information about those problems from her penfriends. But, since Kartini's views on opium was contained in her first letter to Stella Zeehandelaar, this third way of obtaining 
information was very unlikely. Therefore, the first and second ways were the most probable and plausible. The following paragraphs will discuss these two ways in detail.

In the literature, it is mentioned that Kartini, since her childhood, had shown a strong interest in reading. In mastering the Dutch language learned at ELS, Kartini had a yearning to enrich her reading and knowledge. The chance to do so came when her father decided to put her in pingitan and forbade her to continue her study and leave the home. In the beginning, Kartini felt sad and distressed because of losing her freedom, but later she found out her new "freedom" through reading modern books supplied by her brother, RM Sosrokartono, who was studying in the Netherlands. In addition, Kartini could also access her father's reading cupboard, which contained books, newspapers, and magazines. By reading all those materials, Kartini could expand and enrich her knowledge of various social, political, language, culture, and religious issues in the Netherlands Indies as well as in the world (Chudori \& Redaksi KPG (ed.), 2013: 35).

In fact, there is no information in the literature that explains how Kartini followed the discourse about opium in the Netherlands Indies. Indeed the literature does not mention that Kartini read the pamphlets and journals published by the pioneering anti-opium organization at that time, Anti-Opium Bond led by Pieter Brooshooft, the editor of De Locomotief - the biggest newspaper in Central Java that was reported to have an interest on Kartini's writing. The opium problem is not listed in the "main spectrum of Kartini's thoughts," which according to Joost Coté cover only seven aspects, namely: agenda or life plan, feminist ideas, nationalism, modernity, education, Javanese arts and handicrafts, and religion. It is presumed that Multatuli's works, especially his famous novel Max Havelaar, had been a source of inspiration for Kartini's critical views on the colonial government policies (Coté, 2013: 34-35). Yet, it is also possible that Kartini could follow developments about the opiumrelated problem from current affairs issues reported in newspapers that she read in her spare-time.

From the discussion above, it is logical to assume that the most plausible source of Kartini's critical views on opium is the actual condition of indigenous people that she witnessed directly or indirectly in her daily life. If that was the case, the question is how bad were the opium-related problems in Jepara and Rembang, the two cities where Kartini spent her entire life. To answer that question, the first indicator to be seen is the quantity of opium distributed or sold in these regions, and then other related indicators, namely the scale of opium consumption and its immediate socio-economic impact on the users. The following section discusses these indicators which have been sourced from colonial archive and publications.

In general, it can be discerned from these sources that Jepara and Rembang were among the regions in Java where a large quantity of opium was distributed and sold. It was reported, for example, that in 1877 , the official quantity of opium to be distributed and sold in the Residency of Jepara was $9000 \mathrm{kati}$ (1 kati is equal to 618 grams). From this amount, 8250 kati was sold in retail amounts by Chinese opium-farmer (pachter). Ten years later, Jepara still received a similar allocation of 9000 kati, but by this time only 5833 kati was retailed by Chinese pachter. This allocation was much smaller in comparison with the one for the Residency of Rembang, which in 1877 received $15000 \mathrm{kati}$, all of which was retailed by Chinese pachter. By 1887, the total opium allocation for this residency increased to $18000 \mathrm{kati}$, but from this amount, only $6350 \mathrm{kati}$ was retailed by Chinese pachter. Based on this data, it is clear that the Residencies of Jepara and Rembang were among the Javanese regions which had an above average trade in opium. ${ }^{14}$

The next important indicator is the amount of colonial government revenue from opium, which can be used as an indicator of the amount and scale of opium distribution in these regions. Table 1 provides data about government opium revenue per residency.

From Table 1, it can be seen that government revenue from opium in the Residency of Jepara and Rembang steadily increased from 1860 until 1900. In Jepara, the increase however was not as high (from $f 289$ 980 in 1860 to $f 568986$ in 1900) as in Rembang with an enormous increase of more than twofold from $f 303600$ in 1860 to $f 712356$ in 1900 . In comparison with other residencies in Java and Madura, the contribution of opium revenue from these two residencies were slightly higher. This means that in these residencies opium sales were was quite high reflecting high consumption levels. Yet, data about opium users in these two residencies was available only for $1882 / 1883$. In that year, the population of the Jepara residency had reached 857444 people, while the number of casual opium users was 27995 people, while the number of addicted opium users was already 2253 people. So, in total, the number of opium users in Jepara was 30248 people. In the same year, the population of Rembang residency was 1195725 people, and the total number of casual opium users had reached 74664 people: consisting of 70494 casual opium users and 4170 addicted opium users. This places it among the regions with the higher number of addicted opium users.

The last indicator to measure the effects of opium 
Table 1. Government income from opium tax per residency, 1860-1900

\begin{tabular}{|c|c|c|c|c|c|}
\hline Residency & 1860 (f) & 1870 & 1880 & 1890 & 1900 \\
\hline Banten & 76800 & 86520 & \multirow{3}{*}{$823800 *$} & \multirow{3}{*}{$875835^{*}$} & \multirow{3}{*}{$1035763.7^{*}$} \\
\hline Batavia \& Lampung & 535400 & 896520 & & & \\
\hline Krawang & 54600 & - & & & \\
\hline Cirebon & 74040 & 137040 & 202802 & 167394 & 179709.45 \\
\hline Tegal & 159600 & 201600 & 555120 & 350496 & 285330.7 \\
\hline Pekalongan & 48000 & 191040 & 441600 & 285585 & 238062.32 \\
\hline Semarang & 553200 & 733200 & 1608000 & 1682512 & 1707749.5 \\
\hline Jepara & 289980 & 405720 & 460500 & 446561 & 568986 \\
\hline Rembang & 303600 & 570000 & 743220 & 856556 & 712356 \\
\hline Surabaya & 730080 & 816720 & 1305600 & 1340425 & $-* *$ \\
\hline Pasuruan & 114000 & 300120 & 514200 & 512884 & $-* *$ \\
\hline Probolinggo & 31200 & 101400 & 219900 & 229016 & $-* *$ \\
\hline Besuki & 21612 & 93720 & 140502 & 164851 & $-* *$ \\
\hline Banyumas & 74400 & 193200 & 290400 & 214368 & 243438.87 \\
\hline Bagelen & 84000 & 249840 & 239100 & 168101 & 168776.73 \\
\hline Kedu & 120000 & 413040 & 533220 & 298864 & 387688 \\
\hline Yogyakarta & 272400 & 664840 & 663120 & 300371 & 388552 \\
\hline Surakarta & 444000 & 1010400 & 1207500 & 734085 & 1339260 \\
\hline Madiun & 556440 & 1151400 & 1006200 & 760128 & 747022 \\
\hline Kediri & 456000 & 1032000 & 1794000 & 1728376 & 2124298 \\
\hline Madura & 61536 & 192360 & 194760 & 177271 & $-* *$ \\
\hline Java-Madura & 5100888 & 9440640 & 12943002 & 11293679 & 9970873.30 \\
\hline
\end{tabular}

Source: Abdul Wahid, "From Revenue Farming to State Monopolies”, p. 100

consumption in these regions are the social problems that are a consequence of to the habit, particularly criminality. In relation to that issue, the archive of Charles TeMechelen's investigations into opium reveals that in the Residency of Jepara in 1882/1883, there were 6261 criminal cases recorded and 1637 cases of theft. In the same year, the number of recorded crimes committed in the Residency of Rembang was 6795 cases, of which 2 585 were theft. These data were considerably higher in comparison with other residencies in Java and Madura. Concerning Rembang, Charles TeMechelen's report mentions it as one of the important links in the chain of a black market network of opium smuggling in Java, which was boosting the amount of opium consumption there. The data was collected based on the assumption that the higher the opium consumption in a region, the higher the region's crime rate.

Based on data and the indicators mentioned above, it can be said that the Residency of Jepara and Rembang, where Kartini spent most of her life, were the regions with a larger scale of opium sale and distribution than in other regencies in Java. Therefore, it is very likely that Kartini had a chance to directly observe these opium problems occurring in her neighborhood. As part of the most esteemed priyayi family in Rembang and Jepara, Kartini must have been informed about centers of opium business and consumption, which the colonial government officially ran at that time. Kartini's first letter, which contains her critical views on the opium business in Jepara, was written when the government administration of opium business was still in transition from the system of farming-based revenue (pachtstelsel) to the system of government supply chain-based revenue. Meanwhile, Kartini's "anti-opium" views in her second letter was written in Rembang, when the colonial government had established its supply chain monopoly system to 
administer the opium business in the entire colony. In the eyes of Kartini, both systems were the same, especially in the way the colonial government failed to tackle the social effects of opium consumption among indigenous people, and for that reason, Kartini harshly criticized both systems.

\section{CONCLUSION}

It is evident that Kartini showed a very critical attitude and view toward the colonial government's opium policy. Although it was only a small part of her wide spectrum of critical thought that, so far, is seen as focused on the emancipation of indigenous women, her anti-opium views have a signficance, particularly in its contribution to the discourse of anti-opium ideas and anti-opium movement in the Netherlands Indies. Aside from showing another aspect of Kartini's social and political thinking outside what has been known so far, Kartini's anti-opium views brought her into a position as the first Javanese woman and even individual priyayi to contribute to anti-opium discourse in the colony. As has been recognized in past literature, Kartini's views became an important milestone in the emergence of awareness among Javanese priyayi of the opium issue, which affected indigenous people's welfare. This milestone was then followed by Budi Utomo, the prominent Javanese priyayi organization, engaging in and being directly involved in the anti-opium discourse and movement in Java in the following historical period.

It is also clear that Kartini's critical views on the opium problem were shaped by the environmental, community, and historical-geographical context in which she developed as an intellectual. Jepara and Rembang were regions that were impacted by relatively large-scale opium distribution following the introduction of the opium revenue farming system by the colonial government in the 1820s. The social problems that arose from opium consumption drew Kartini's attention and concern. In her eyes, the empowerment of Javanese women should begin with their families' economic empowerment; however, opium consumption - mostly by Javanese husbandsgradually destroyed the foundation of Javanese household incomes, resulting in poverty, criminality, and violence. For that reason, Kartini considered opium to be "a curse for the Javanese," which ironically became "the blood life" of the government of the Netherlands Indies. This led Kartini to label the colonial government's opium business as "the most-evil crime" that was like a plague on indigenous people's lives in Jepara, Rembang, and the Netherlands Indies in general, until the end of the colonial period.

\section{ACKNOWLEDGEMENT}

Research for this article was funded by Annual Grant of the Faculty of Cultural Sciences, Universitas Gadjah Mada, Fiscal Year of 2020. I would like to thank Joost Coté for his valuable comments on an earlier version of this paper, and to Thomas Joko Priyambodo and David Rawson for their editing of this article.

\section{ENDNOTES}

1) See for example, the latest publication about Kartini by Bijl and Chin (2020)

2) The popularity of Kartini in the collective memory of Indonesian society has generated different kinds of myths about her. See Cora Vrede de Stuers (1965).

3) Kartini \& Abendanon (ed.) (1911). This edition was republished in 1912, and the Indonesian version of the book was published a decade later (1922) by Balai Pustaka (Volkslectuur) under title Habis Gelap Terbitlah Terang: Boeah Pikiran, while the Javanese version was published in 1938 under title: R.A. Kartini: Mboekak Pepeteng (1938).

4) According to her siblings, Kartini never showed any remorse for being a daughter of a selir (semi-official wife), though she never also discusses explicitly that issue in her letters. See Sumartana (2013: 7-8).

5) In Pramoedya Ananta Toer's view, the open-mindedness of Raden Mas Adipati Sosrodiningrat was a product of his education. He was one of only four Javanese bupati who was the product of the Western education system in Java. See Toer (2003: 65).

6) This attitude of Bupati Sosrodiningrat was related to the fact that he was a bupati who needed to preserve local adat and tradition and could only accept a highly selective range of ideas on progress otherwise he would lose his position (Toer, 2003: 65; Sumartana, 2013: 10).

7) Karitini's ten Dutch penfriends are 1) Estelle H. Zeehandelaar; 2) Mrs. M.C.E. Ovink-Soer; 3) Mr. and Mrs. Prof. dr. G.K. Anton di Jena; 4) Dr. N. Adriani, zendeling in Poso; 5) Mrs. H.G. de Booij-Booisevain; 6) Ir. H.H. van Kol, member of Social Democratic Party of the Netherlands; 7) Mrs. N. van Kol; 8) Mrs. R.M. Abendanon-Madri; 9) Mr. J.H. Abendanon; 10) E.C. Abendanon, daughter of Mr and Mrs. Abendanon. See Sumartana (2013: 32-33).

8) All English versions of Kartini's letters cited in this article are taken from Coté (2013: 71). As a comparison, the Indonesian version of Kartini's letter in this part is taken from Kartini \& Ari P (2018: 5).

9) On the reforming process of the opium farming system atau opiumpacht see Wahid (2013: 150-152). 
10)(Coté, 2013: 72). Curiously, the last sentence of Kartini's letter in this paragraph has been deleted from the first version of Abendanon's editing of Kartini's letter, as does the Indonesian edition of Kartini (2018: 6). The reasons for this deletion is not clear. Yet, according to Joost Coté, this was part of the censorship done by the Dutch editor due to sensitivity of the opium issue at that time, which is applied to Kartini's second letter on opium.

11) In his celebrated work, James Rush calls opium a 'sinister friend' (friend that brings harms) of the Javanese throughout the nineteenth Century (Rush, 2007: 26-42).

12) This group calls themselves 'Anti-opium Bond', which was established in 1890. Pieter Brooshooft, the editor of De Locomotief, was a progressive and critical of colonial government policy, and one of the activists in that group. This organization published a journal: "Opium-vloek op Java: Tijdschrift of Anti-opium Bond” (Rush, 2007: 198-216).

13) Here, we can also argue that for Kartini, her marriage to the Regent of Rembang was actually part of her strategy to get support and access in achieving her ideals to protect and empower her people, the Javanese. I acknowledge Joost Coté for his insight on this point.

14) Special Collection Leiden University Library, KITLV, H 422 (a), "Rapport uitgebracht in Voldoening aan s'Gouvernement Besluit d.d. 9 Juli 1885 door Charles TeMechelen, Resident van Rembang". Herewith this archive will be referred as "Charles TeMechelen's report."

\section{REFERENCES}

Baha’Uddin (2000). Pelayanan Kesehatan Masyarakat Pada Masa Kolonial. Lembaran Sejarah, 2(2), 103-123.

Bijl, Paul \& Chin, Grace V.S. (2020). Appropriating Kartini: Colonial, National, and Transnational Memories of An Indonesian Icon. Singapore: ISEAS - Yosef Ishak Institute.

Bijl, Paul (2017). Legal Self-fashioning in Colonial Indonesia: Human Rights in the Letters of Kartini. Indonesia, 103 (April 2017), 51-71.

Chudori, Leila \& Redaksi KPG (ed.) (2013). Gelap Terang Hidup Kartini. Seri Buku Tempo: PerempuanPerempuan Perkasa. Jakarta: Kepustakaan Populer Gramedia.

Connell, Raewyn (2010). Kartini's Children: on the need for thinking gender and education together on a world scale. Gender and Education, 22(6), 2010, 603-615;

Coté, Joost (Ed.) (2008). Realizing the Dream of R.A. Kartini: Her Sisters' Letters from Colonial Java. Athens/Leiden: Ohio University Press \& KITLV Press.
Coté, Joost (Ed.) (2013). Kartini; The Complete Writings, 1898-1904. Clayton: Monash University Publishing.

Deventer, C. Th. van (1912). Kartini. Amsterdam: Maatschappij voor Goede en Goedkope Lectuur.

Febriana, Efatino (2010). Kartini Mati Dibunuh. Membongkar Hubungan Kartini dan Freemason. Benarkah Pemikiran Kartini dipengaruhi Yahudi? Yogyakarta: Navila Idea.

Ganie, Suryatini N. (2005). Kisah dan Kumpulan Resep Putri Jepara: Rahasia Kuliner R.A. Kartini, R.A. Kardinah, R.A. Roekmini. Jakarta: Gaya Favorit Press.

Kartini, Raden Adjeng (1911). Door duisternis tot licht: gedachten over en voor het Javaansche Volk (J. H. Abendanon, Ed.). Semarang/Den Haag: Van Dorp \& Co.

Kartini, Raden Adjeng (1921). Letters of A Javanese Princess (Agnes L. Symmers, Ed. with a foreword by Louis Couperus). London: Duckworth \& Co.

Kartini, Raden Adjeng (1922). Habis Gelap Terbitlah Terang: Boeah Pikiran (J. H. Abendanon, Ed.). Weltevreden: Balai-Poestaka, 1922.

Kartini, Raden Adjeng (1938). Habis Gelap Terbitlah Terang (Armijn Pane, Ed.). Batavia: Balai Poestaka.

Kartini, Raden Adjeng (1938). R.A. Kartini: Mboekak Pepeteng (J. H. Abendanon, Ed.). Soerabaja: Panitya Fonds Kartini Djawa.

Kartini, Raden Adjeng (1964). Letrres de Raden Adjeng Kartini: Java en 1900 (L.C. Damais \& Jeanne Cuisinier, Ed. \& Trans.). Paris/La Haye: Mouton.

Kartini, Raden Adjeng (1964). Raden Adjeng Kartini: Letters of A Javanese Princess (Eleanor Roosevelt $\&$ Hildred Geertz, Ed. \& Trans.). New York: Norton.

Kartini, Raden Adjeng (1979). Surat-surat Kartini: Renungan tentang dan untuk Bangsanya (Sulastin Sutrisno, Ed.). Jakarta: Djambatan.

Kartini, Raden Adjeng (1992). Letters from Kartini: An Indonesian Feminist, 1900-1904 (Joost Coté, Trans.). Clayton: Monash Asia Institute, Monash University.

Kartini, Raden Adjeng (2005). On Feminism and Nationalism: Kartini's Letters to Stella Zeehandelaar, 1899-1903 (Joost Coté, Trans.). Clayton: Monash Asia Institute, Monash University.

Kartini, Raden Adjeng (2018). Habis Gelap Terbitlah Terang. Door Duisternis tot Licht (Ari P., Ed.) $1^{\text {st }}$ edition. Yogyakarta: Penerbit Narasi.

Latif, Syahril A. (1983). Kenangan bagi Pahlawan Tanah Air, R.A. Kartini: Puisi untuk Anak-anak. Jakarta: Pustaka Dian.

Mahy, Petra (2012). Being Kartini: Ceremony and Print Media in the Commemoration of Indonesia's First Feminist. Intersections, 28, 33-48.

Pramoedya Ananta Toer (2003). Panggil Aku Kartini Saja. Jakarta: Lentera Dipantara. 
Rush, James R (1990). Opium to Java. Revenue Farming and Chinese Enterprise in Colonial Indonesia, 18601910. Ithaca: Cornell University.

Salam, Solichin (1983). Kartini dalam Sejarah Nasional Indonesia. Jakarta: Menara Kudus.

Sastroatmodjo, Suryanto (1970). R.A. Kartini dan Kebudajaan. Bodjonegoro: Lingkaran Studi Seni Proporsi.

Sastroatmodjo, Suryanto (1977). Tragedi Kartini: Sebuah bahan studi kompartaif \& analitis untuk appresiasi soal-soal emansipasi di Indonesia. Yogyakarta: Wirofen Group.

Soemoatmodjo, Soekesi (1981). Sekolah Kartini: Suatu usaha untuk menyebarkan dan meningkatkan kecerdasan wanita pada permulaan abad ke-20. Paper in Seminar Sejarah Nasional ke-3, Jakarta, 10-14 Nopember 1981. Jakarta: Proyek Inventarisasi dan Dokumentasi Sejarah Nasional, Direktorat Sejarah dan Nilai Tradisional, Departemen Pendidikan dan Kebudayaan.

Stuers, Cora Vrede de. (1965). Kartini: Fieten en Ficties. 's-Gravenhage: Nijhoff.

Subandrio, Hurustriati (1950). Kartini. Jakarta: Djambatan. Sumartana, Th. (1993). Tuhan \& Agama dalam Pergulatan Batin Kartini. Jakarta: Pustaka Utama Grafiti.

Suroto, Siti Sumandari (1977). Kartini: Sebuah Biografi. Jakarta: Gunung Agung.
Tashadi, R.A. (date). Kartini. Jakarta: Proyek Biografi Pahlawan Nasional, Departemen Pendidikan dan Kebudayaan.

Ulum, Amirul (2019). Kartini Nyantri. Yogyakarta: Global Press.

Wahid, Abdul (2013). From Revenue Farming to State Monopolies: The Political economy of Taxation in Colonial Indonesia, Java ca 1816-1942. PhD Thesis, University of Utrecht.

Zeggelen, Marie C. van (1945). Kartini: een baanbreekster voor haar volk: roman. Amsterdam: J.M. Meulenhoff.

\section{Archive}

Special Collection Leiden University Library, KITLV H 422 (a), "Rapport uitgebracht in Voldoening aan s'Gouvernement Besluit d.d. 9 Juli 1885 door Charles TeMechelen, Resident van Rembang".

\section{Internet}

Fathurrozak, Selasa 21 April 2020. "Kartini-kartini dalam sinema nasional", Media Indonesia. https:// mediaindonesia.com/read/detail/306014-kartinikartini-dalam-sinema-nasional. Accessed on 14 October 2020 . 